\title{
IMPLEMENTASI PELESTARIAN BANGUNAN HOTEL SEBAGAI BANGUNAN BERSEJARAH BERWUJUD (STUDI KASUS PADA HOTEL MAJAPAHIT SURABAYA DAN GRAND INNA YOGYAKARTA)
}

\author{
Aditya Pratomo \\ Fakultas Ekonomi Dan Komunikasi, Hotel Management \\ Universitas Bina Nusantara \\ Jl. K. H. Syahdan No 9 Kemanggisan/Palmerah Jakarta Barat \\ Email Korespondensi: pratomo_aditya@binus.ac.id
}

\begin{abstract}
ABSTRAK
Penelitian ini bertujuan untuk mencari tahu apakah hotel yang termasuk dalam kategori warisan budaya memiliki keunggulan tersendiri ditengah perkembangan hotel moderen saat ini, khususnya di kota- kota besar seperti Surabaya dan Daerah Istimewa Yogyakarta. Kemudian, penelitian ini juga mengklarifikasi apakah keberadaan dan eksistensi hotel sebagai bangunan pusaka layak untuk dipertahankan, serta apa keuntungan yang didapat dan apa saja tantangan yang dihadapi. Kemudian bagaimana Penanganan strategis guna melihat keunggulan dari penggunaan bangunan warisan budaya serta kendala yang dihadapi. Penelitian ini menggunakan metode analisis deskriptif kualitatif. Data primer diperoleh dari survei kuesioner dan wawancara dengan perwakilan dari pengelola hotel. Penelitian dilakukan di hotel yang tercatat secara resmi sebagai situs warisan budaya di Indonesia. Hasilnya akan memberikan gambaran besar yang mendalam dengan mengacu kepada konsep heritage hotel yang berwujud, karakteristik, keuntungan yang kompetitif, strategi manajemen serta operasional dari hotel secara keseluruhan beserta tantangan yang mungkin terjadi. Pengumpulan data didapat dari sudut pandang pihak pengelola hotel (dalam hal ini pihak manajemen). Penelitian ini memberikan kontribusi kepada pemahaman yang mendalam tentang industri perhotelan, terutama konsep penggunaan bangunan warisan budaya.
\end{abstract}

Kata kunci: Hotel, Cagar Budaya, Heritage Hotel yang Berwujud, Bangunan Warisan Budaya yang Berwujud

\begin{abstract}
This research aims to find out if the hotel is included in the category of cultural heritage has its own advantages in the middle of the development of the modern hotel today, especially in big cities like Surabaya and Yogyakarta. Then, the study also clarify whether the existence and existence of the hotel building heirloom deserves to be preserved, as well as what a benefit and what are the challenges faced. Then how the handling of strategic to see the advantages of the use of cultural heritage buildings as well as obstacles encountered. This research uses qualitative, descriptive methods of analysis. Primary data obtained from the survey questionnaires and interviews with representatives from the property. Research done in the hotel which was recorded officially as a heritage site in Indonesia.The results will give you the big picture of the deep with reference to the concept of heritage hotel that intangible, characteristics, competitive advantages, strategy and operational management of the hotel as a whole along with challenges that may occur. The collection of data obtained from the point of view of the parties the property (in this case the management). This research contributes to a deep understanding of the hospitality industry, especially the concept of the use of cultural heritage buildings.
\end{abstract}

Keywords: Hotel, Cultural Heritage, Intangible Heritage Hotel, Tangible Cultural, Heritage Buildings 


\section{PENDAHULUAN}

Perjalanan manusia pada titik-titik tertentu meninggalkan rekaman yang menjadi warisan budaya. Warisan budaya, menurut Davison (1991: 2) diartikan sebagai produk atau hasil budaya fisik dari tradisi-tradisi yang berbeda dan prestasi-prestasi spiritual dalam bentuk nilai dari masa lalu yang menjadi elemen pokok dalam jatidiri suatu kelompok atau bangsa. Dari gagasan ini, warisan budaya merupakan hasil budaya fisik (tangible) dan nilai budaya (intangible) dari masa lalu.

Indonesia sendiri, merupakan negara yang kaya akan peninggalan budaya, alam, dan bahkan arsitektur. Warisan budaya mencakup material yang berwujud seperti rumah adat, pakaian adat, prasasti, candi, monument, arsitektur bangunan, dan peralatan. Kemudian warisan budaya yang tidak berwujud seperti lagu daerah, upacara adat, gaya hidup, cerita rakyat, norma dan tata nilai. Menurut Kleden dan Fanani (2012) Peninggalan budaya merupakan rekaman dasar pemikiran dan aktivitas manusia pada masanya. Peninggalan budaya di Indonesia sudah menjadi kewajiban negara untuk memberikan perlindungan, pengelolaan dan penafsiran yang tepat sangat penting untuk kemanfaatan generasi sekarang dan mendatang. Klasifikasi peninggalan atau warisan budaya yang berwujud dapat dibagi menjadi tiga jenis yang berbeda yaitu buildings and archaeological site; herirgae cities, routes, and cultural landscapes; and and movable cultural property and museums. Building and archaeological adalah jenis warisan budaya berwujud yang paling umum (McKercher; Cros, 2012: 65). Menurut UU No 28/2002, Bangunan gedung adalah wujud fisik hasil pekerjaan konstruksi yang menyatu dengan tempat kedudukannya, sebagian atau seluruhnya berada di atas atau di dalam tanah atau air, yang berfungsi sebagai tempat manusia melakukan kegiatannya, baik untuk hunian atau tempat tinggal, kegiatan keagamaan, kegiatan usaha kegiatan sosial, budaya, maupun kegiatan khusus.

Berdasarkan undang-undang no 11 tahun 2010 tentang Warisan Budaya, pasal 5 menyatakan bahwa benda, bangunan, atau struktur warisan budaya apabila memiliki kriteria atau ciri-ciri: 1 . Berusia 50 tahun atau lebih, 2. Mewakili masa gaya paling singkat berusia 50 tahun, 3. Memiliki arti khusus bagi sejarah, ilmu pengetahuan, pendidikan, agama, dan atau kebudayaan, 4. Memiliki nilai budaya bagi penguatan kepribadian bangsa. Sedangkan dalam pasal 7 dijelaskan bahwa Bangunan Warisan Budaya dapat berupa:1. Berunsur tunggal atau banyak, 2. Berdiri bebas atau menyatu dengan formasi alam (Tonapa; Rondonuwu; Tungka, 2015). Menurut Xie, Philip Feifan (2015: 45) melestarikan dan mempertahankan sebuah warisan budaya memiliki beberapa hambatan seperti kurangnya kesadaran masyrakat sekitar, kurangnya tolak ukur ekonomi, dan kompleksitas spasial dan regional. Selain itu ada beberapa hal yang menyebabkan proses pelestarian suatu kawasan tidak berjalan, sehingga menimbulkan degradasi lingkungan adalah: 1. Tidak didukung oleh semua pihak atau stakeholders. 2. Tidak adanya kejelasan tujuan pelestarian, serta komitmen bersama antara stakeholder tentang tujuan dan criteria pelestarian kawasan. 3. Tidak adanya konsep dan acuan penataan ruang serta bangunan yang jelas, bagi kawasan yang ingin dilestarikan.

Surabaya merupakan salah satu kota yang melatar-belakangi perang kemerdekaan Indonesia. Kemenangan rakyat Surabaya menjadi penyalur semangat merdeka dan menjadi pelopor revolusi kemerdekaan Indonesia. Hal ini menjadikan Surabaya memiliki banyak warisan budaya yang berwujud dan tidak berwujud. Namun pemerintah Indonesia baik pemerintah pusat, daerah maupun swasta masih belum memaksimalkan warisan budaya tersebut untuk dijadikan sebuah Heritage Tourism. Banyak bangunan yang berubah fungsi dan masih mempertahankan bentuk aslinya, namun lebih banyak 
bangunan yang berubah fungsi serta menghilangkan bentuk aslinya. Salah satu bangunan yang masih dipertahankan bentuk aslinya adalah Hotel Majapahit yang berlokasi di Jalan Tunjungan No.65, Genteng, Surabaya.

Hotel Majapahit adalah lokasi terjadinya peristiwa heroik yaitu perobekan sebuah bendera Belanda yang dikibarkan pada saat Indonesia resmi merdeka tanpa persetujuan pemerintah daerah Surabaya. Hal ini membuat Arek-Arek Suroboyo marah dan merobek bendera Belanda yang berwarna biru menjadi bendera Indonesia yang berwarna merah dan putih. Hingga kini bangunan Hotel Majapahit masih asli namun untuk keperluan perluasan halaman kedua buah menara yang berada di kiri kanan pintu masuk dihancurkan. Hotel Majapahit adalah sebuah warisan budaya yang berwujud bangunan masih dilindungi pemerintah di Surabaya. Hotel Majapahit mengalami beberapa kali pergantiaan nama seperti Hotel Oranje, Hotel Yamato, Hotel Merdeka, L.M.S Hotel, dan kini Hotel Majapahit telah mengalami perubahan manajemen dimana Hotel Majapahit berada dibawah manajemen grup Accor dan akan berubah nama menjadi Sofitel. Namun hingga kini belum dilaksanakan dan belum ada perubahan nama maupun manajemen. Bukan hanya di Surabaya beberapa propinsi di Indonesia terdapat warisan budaya berupa bangunan seperti di Daerah Istimewa Yogyakarta. Di Daerah Istimewa Yogyakarta terdapat sebuah hotel bernama Grand Inna, yang berlokasi di Jalan Malioboro No.60, Suryatmajan, Danurejan, Daerah Istimewa Yogyakarta, 55213. Hotel ini merupakan markas besar utama (MBU) tentara keamanan rakyat yang dipimpin oleh Jendral Sudirman salah satu tokoh pahlawan dan perwira tinggi Indonesia pada masa Revolusi Nasional Indonesia.

Keadaan politik saat itu masih belum aman sehingga Ibu Kota Indonesia dipindahkan sementara ke Daerah Istimewa Yogyakarta. Pada tahun 1950 Hotel Merdeka berubah fungsi kembali menjadi Hotel dengan nama Hotel Garuda. Hotel Inna Garuda mengalami pergantian nama beberapa kali seperti Grand Hotel de Jogja, Hotel Asahi, Hotel Merdeka, dan sekarang menjadi Hotel Grand Inna Yogyakarta dibawah Hotel Indonesia Group (HII). Hotel Grand Inna Yogyakarta masih mempertahankan keaslian dari bangunan di beberapa bagian seperti area lobby, sayap kanan dan sayap kiri hotel, serta air mancur. Namun untuk bagian dalam hotel yang lain sudah mengalami perubahan untuk mengikuti perkembangan zaman.

Penjelasan di atas, maka penelitian ini bertujuan untuk mencari tahu apakah hotel yang termasuk dalam kategori Warisan budaya memiliki keunggulan tersendiri ditengah perkembangan hotel moderen saat ini, khusunya di kota- kota besar seperti Surabaya dan Daerah Istimewa Yogyakarta. Kemudian, penelitian ini juga untuk mengetahui apakah keberadaan dan eksistensi hotel sebagai bangunan pusaka layak untuk dipertahankan, serta apa keuntungan yang didapat dan apa saja tantangan yang dihadapi.

\section{METODE PENELITIAN}

Penelitian ini adalah penelitian kualitatif dimana dalam penelitian ini lebih menekankan pada proses keterlibatan peneliti dengan fakta yang diteliti sehingga lebih bersifat subyektif dalam bentuk hasil penelitian yang bersifat naratif. Cara kerja yang dilakukan peneliti adalah melalui proses pengumpulan serta penyaringan data untuk melihat hubungan saling keterkaitan dari berbagai informasi terkait data tersebut". Teknik analisis yang digunakan adalah analisis tema budaya, yaitu teknik yang berupaya mencari "benang merah" yang mengintegrasikan lintas domain yang ada. Dalam penelitian ini populasi diambil dari hotel Majapahit di Surabaya dan hotel Hotel Inna Garuda di 
Yogyakarta. Dengan sumber data primer dan skunder, adapun sumber data primer dalam penelitian ini adalah informasi data diperoleh melalui wawancara secara langsung kepada narasumber, mereka adalah pada stakeholder hotel Majapahit di Surabaya dan hotel Hotel Inna Garuda di Yogyakarta. Sedangkan sumber skunder didapat melalui bahan kepustakaan, berupa buku-buku, jurnal-jurnal, maupun jurnal penelitian terdahulu. Adapun metode pengumpulan data dalam penelitian ini menggunakan metode wawancara mendalam. Metode wawancara menggunakan jenis wawancara semi-terstruktur, karena proses wawancara bersifat fleksibel dan dapat menyesuaikan dengan kondisi lapangan tetapi tetap ada pedoman awal wawancara sebagai acuan agar proses wawancara dapat tetap berjalan sesuai dengan tujuan penelitian.

Dalam penelitian ini teknik analisis data meliputi beberapa tahapan, yakni: Pertama: Reduksi data, bentuk analisis yang mengorganisasikan data secara terstruktur dengan cara menggolongkan dan memilih sesuatu yang dianggap penting, sehingga dapat menajamkan analisis sedemikian rupa. Kedua: Penyajian data dengan menyusun suatu informasi, dan menyajikannya dalam bentuk narasi. Ketiga: Penarikan Kesimpulan atas data-data yang telah diperoleh dan disajikan sehingga dapat digunakan untuk mengambil tindakan. Teknik ini merupakan teknik pemeriksaan keabsahan data yang memanfaatkan sesuatu yang lain di luar data sebagai pembanding terhadap data tersebut (Pawito, 2007). Selain teknik tringgulasi, penelitian ini juga menggunakan teknik observasi, dimana pengumpulan data yang dilakukan dengan pengamatan langsung dan pencatatan secara sistematis terhadap obyek yang diteliti. (Margono: 2007). Observasi yang dilakukan dalam peneliti ini dengan cara pengamatan langsung terhadap kondisi hotel Majapahit di Surabaya dan hotel Hotel Inna Garuda di Yogyakarta. 


\section{KERANGKA PEMIKIRAN}

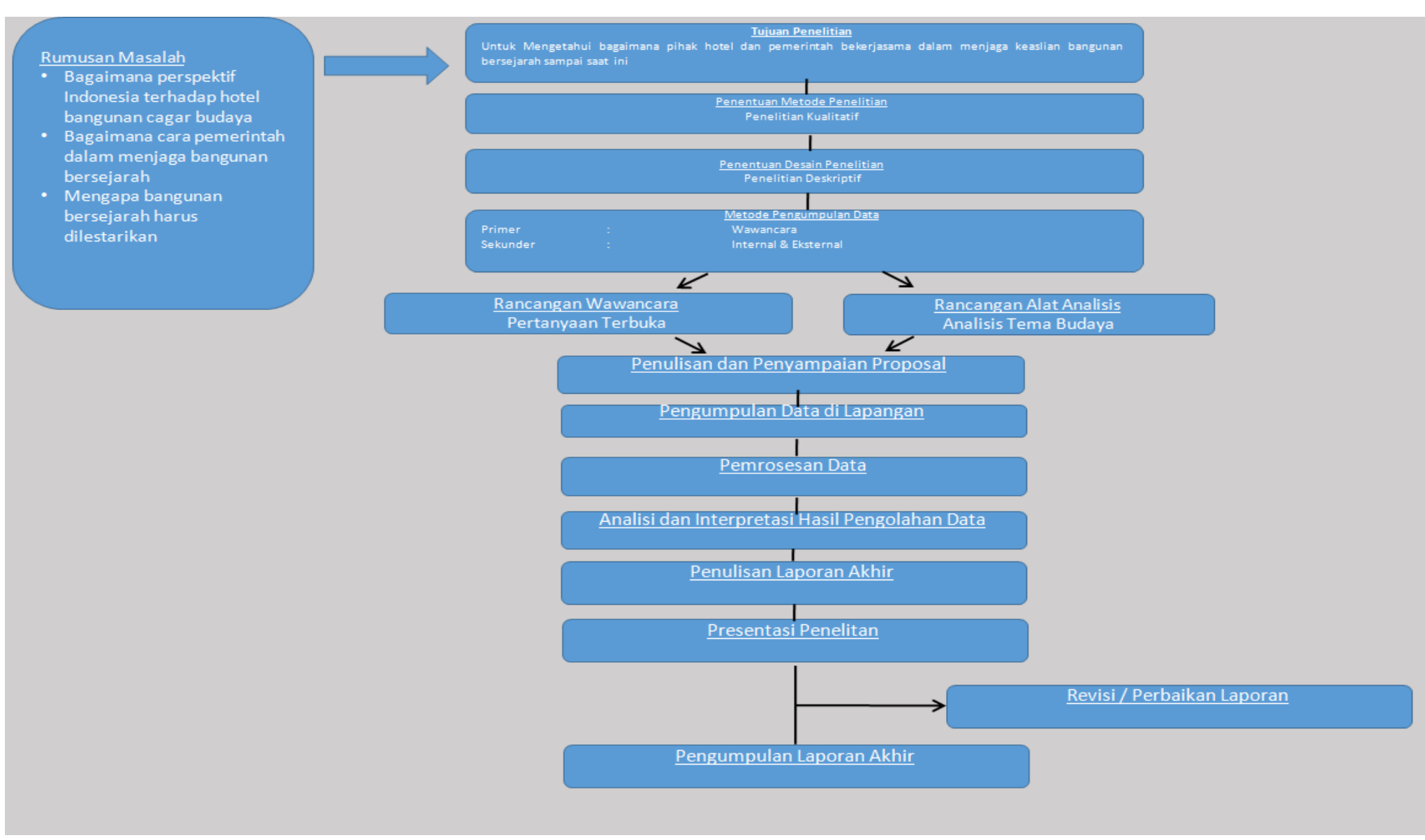

Gambar 1. Kerangka Pemikiran 


\section{HASIL DAN PEMBAHASAN}

\section{Analisis Klasifikasi Hotel Sebagai Warisan Budaya Yang Berwujud}

Warisan budaya atau heritage yaitu sejarah, tradisi, dan nilai - nilai yang dimiliki suatu bangsa atau Negara selama bertahun-tahun dan dianggap sebagai bagian penting dari karakter bangsa tersebut. (Sumber: Kamus Oxford hal: 202). UNESCO memberikan definisi generasi ke generasi karena memiliki nilai- nilai luhur. Dalam buku Heritege Management Interpretation Idewntity, karya Peter Howord memberikan makna heritage sebagai segala sesuatu yang ingin diselamatkan orang, termasuk budaya material maupun alam. Sedangkan menurut Hall \& McArther (1996:5) dalam bukunya heritage management memberikan definisi heritage sebagai warisan budaya dapat berupa kebendaan (tangible) seperti monument, arsitektur bangunan, tempat peribadatan, peralatan, kerajinan tangan, dan warisan budaya yang tidak berwujud kebendaan (intangible) berupa berbagi atribut kelompok atau masyarakat, seperti cara hidup.

Berdasarkan kajian pustaka dan hasil interview yang didapat dari dua sampel yakni hotel Majapahit Surabaya dan Grand Inna Yogyakarta, maka dapat dijelaskan lebih lanjut mengenai kriteria apa saja yang menjadikan sebuah hotel diklasifikasikan sebagai bagunan warisan budaya, yaitu sebagai berikut: pertama: Hotel memiliki nilai kelangkaan, yaitu karya arsitekturnya merupakan sesuatu yang langka. Di Indonesia hanya terdapat lima hotel yang dikategorikan sebagai bangunan warisan budaya. Sedangkan menurut data pada Badan Pusat Statistik (www.bps.go.id) pada tahun 2015 terdapat 2.197 hotel berbintang. Maka dapat dikatakan bahwa hanya terdapat $0,22 \%$ hotel yang diklasifikasikan sebagai hotel warisan budaya.

Kedua: Sebuah Hotel yang memiliki nilai sejarah yaitu hotel yang lokasinya menjadi tempat terjadinya sejarah penting. Seperti halnya hotel Majapahit, karena hotel ini merupakan tempat bersejarah terjadinya perobekkan bendera Belanda namun pada saat itu Indonesia telah merdeka. Arek-arek Suroboyo yang melihat kesengajaan Belanda mengibarkan bendera tersebut memicu antara Indoneseia-Belanda. Karena tidak menemukan titik temu, para arek-arek Suroboyo naik ke atas hotel Majapahit dan merobek bendera Belanda. Selain itu Hotel Majapahit pernah mendapat kunjungan dari artis pada tahun 1936 Charlie Chaplin dan Paulette Goddar untuk menghadiri peresmian hotel dan terdapat kamar yang menjadi tempat dimana perdebatan antara Indonesia-Belanda yaitu Kamar Merdeka dengan nomor kamar 33. Begitu juga dengan hotel Grand Inna Yogyakarta yang merupakan tempat bersejarah karena dahulunya adalah markas besar utama (MBU) tentara yang dipimpin Jendral Sudirman salah satu tokoh pahlawan dan perwira tinggi Indonesia pada masa Revolusi Nasional Indonesia. Menjadi panglima besar Tentara Nasional Indonesia pertama, ia secara luas terus dihormati di Indonesia. Kantor tersebut sekarang dijadikan salah satu kamar di Grand Inna Yogyakarta dengan tipe Presedential Suite. Mantan Presiden Indonesia Bapak Susilo Bambang Yudhoyono pernah menginap di Grand Inna Yogyakarta untuk menghadiri dan meresmikan sebuah acara. 
Ketiga: Hotel memiliki nilai superlativitas, yaitu memiliki predikat ter-, misalnya tertua, terbesar, tertinggi, terpanjang. Hotel Majapahit merupakan hotel tertua di Surabaya dibangun sejak 1910. Selain itu Hotel Majapahit mendapatkan Certificate of Excellence Hall of Fame dari Tripadvisor selama 5 tahun berturut-turut dan menjadi Favorite Hotel in Indonesia. Hotel Grand Inna Yogyakarta mendapatkan Certificate of Excellence 2011 dari Tripadvisor.

Keempat: Hotel memiliki nilai kezamanan, yaitu karya yang mewakili suatu jenis ragam bangunan tertentu. Hotel Majapahit memiliki jenis bangunan bercorak art-deco yang banyak sekali kita temui pada bangunan-bangunan bergaya kolonial Belanda jaman dahulu. Namun sekarang diubah menjadi art nouveau. Kelima: Hotel memiliki benda yang bernilai sejarah. Hotel Majapahit masih memiliki beberapa benda yang bernilai bersejarah hingga kini masih digunakan untuk operasional hotel dan tamu seperti kursi, lampu hias, telepon, bel, toilet, lemari, dan hiasan kuno. Hotel Grand Inna Yogyakarta masih memiliki benda yang bernilai sejarah seperti engsel pintu yang masih asli buatan Belanda menurut Dinas Kebudayaan Yogyakarta.

Kelima: Hotel memiliki nilai estetika, yaitu mempunyai keindahan bentuk struktur dan ornamen tertentu. Salak memiliki keindahan bagian hotel yang masih dipertahakan bentuk aslinya dari pintu masuk ke lobi lalu koridor hingga areal kolam renang. Savoy dan Preanger mewakili struktur art deco yang bukan hanya di areal umum namun juga interior di dalam kamar tamu. Desain kamar tamu yang ditampilkan sangat heritage, dimana mereka masih mempertahankan beberapa furniture peninggalan masa lalu. Gaya art deco ini memiliki makna yaitu aliran atau faham dalam mendesain sebuah objek berupa bangunan yang banyak memiliki unsur garis, bidang, lengkungan dan bentuk geometri

Keenam: Hotel memberikan pengaruh, yaitu keberadaanya akan meningkatkan citra lingkungan sekitarnya. Hotel berdiri bukan hanya sebagai sumber bisnis semata, namun juga keberadaannya memberikan dampak yang positif bagi lingungan sekitar. Lingkungan yang dimaksudkan disini adalah masyarakat dan juga areal lingkungan. Salak memberikan kesempatan lapangan kerja khususnya bagi orang lokal yang berasal dari Bogor. Savoy dan Preanger secara berkala melaksanakan kegiatan Corporate Social Responsibility misalnya seperti donor darah, kegiatan sosial ataupun memberikan fasilitas tempat untuk beribadah.

\section{Analisis Motif Manajemen Dalam Mempertahankan Keaslian Hotel}

Dalam piagam pelestarian pusaka Indonesia dideklarasikan di Ciloto 13 Desember 2003, heritage disepakati sebagai pusaka. Pusaka (Heritage) Indonesia meliputi: Pusaka alam yang istimewa seperti, Taman Nasional Komodo, Taman Nasional Ujunng Kulon, Taman Nasional Lorentz, dan Cluster Tropikal Heritage of Sumatra. Kemudian pusaka budaya yang berupa hasil cipta, rasa, karsa, dan karya yang istimewa dari lebih 500 suku bangsa di tanah air Indonesia. Dan yang terakhir pusaka saujana yang merupakan gabungan pusaka alam dan pusaka budaya dalam kesatuan ruang dan waktu.

Berdasarkan kajian pustaka dan hasil interview yang didapat dari dua sampel, maka dapat dijelaskan lebih lanjut mengenai motif apa yang melatarbelakangi manajemen atau korporasi hotel mempertahankan keaslian bangunan hotel, yaitu sebagai berikut: Pertama: Dengan dipertahankannya keaslian bangunan hotel sebagai warisan budaya, maka hotel 
dianggap mempunyai nilai penting bagi sejarah, ilmu pengetahuan dan budaya serta benda alam yang dianggap memiliki nilai penting bagi sejarah, ilmu pengetahuan dan kebudayaan. Kedua: Dengan dipertahankannya keaslian bangunan hotel sebagai warisan budaya, maka hotel turut serta memelihara kelangsungan hidup bangunan yang memiliki nilai sejarah dengan cara memanfaatkannya sesuai dengan fungsi masa sekarang tanpa menghilangkan ciri aslinya. Ketiga: Dengan dipertahankannya keaslian bangunan hotel sebagai warisan budaya, maka hotel turut andil dalam menyebarluaskan informasi tentang pentingnya bangunan warisan budaya dan sejarah yang mengikutinya. Keempat: Dengan dipertahankannya keaslian bangunan hotel sebagai warisan budaya, maka hotel turut serta dalam mempertahankan citra negara Indonesia sebagai negara yang memiliki peninggalan arsitektur yang kaya. Kelima: Dengan dipertahankannya keaslian bangunan hotel sebagai warisan budaya, maka hotel memiliki nilai lebih dari hanya sekedar menyediakan akomodasi. Keenam: Dengan dipertahankannya keaslian bangunan hotel sebagai warisan budaya, maka hotel menjadi satu dari sekian banyak hotel yang memiliki keunikan tersendiri. Ketujuh: Dengan dipertahankannya keaslian bangunan hotel sebagai warisan budaya, maka hotel berharap dapat menarik dan juga tentunya mendapatkan market yang lebih luas, misalkan niche market yang menyukai hal-hal yang berbau heritage. Kedelapan: Dengan dipertahankannya keaslian bangunan hotel sebagai warisan budaya, maka hotel berharap dapat berada pada kelasnya tersendiri, terlepas dari kategori bintang yang dipegangnya, namun hotel mempunyai kategori yang jarang dimiliki hotel lain pada umumnya yaitu heritage hotel. Kesembilan: Dengan dipertahankannya keaslian bangunan hotel, hotel memiliki nilai seni yang lebih tinggi dibandingkan hotel yang mengambil konsep heritage.

\section{Analisis Keunggulan Kompetitif Status Hotel Sebagai Warisan Budaya Berwujud}

Inna Garuda merupakan hotel bintang empat yang mengusung konsep sebagai hotel Convention \& Business. Dan salah satu hotel yang dikhususkan sebagai Meeting, Incentive, Convention, Exhibition (MICE) destinations. Dan merupakan salah satu hotel yang memiliki nilai sejarah dan merupakan hotel heritage yang ada di Indonesia.

Hotel Inna Garuda sebagai salah satu hotel bintang empat di Jogjakarta dan merupakan hotel yang memiliki nilai sejarah yang harus dijaga dan dilestarikan keberadaanya. Hotel Inna Garuda dengan segala keunikan yang dimilikinya menjadikan nilai lebih untuk tetap menjaga dan mempertahankan di tengah persaingan industri hotel lain yang modern. Untuk dapat bersaing dengan hotel moderen lainnya, Inna Garuda tidak saja menjual nilai sejarah dan budaya Jogjakarta, hotel ini juga meningkatkan kualitas disegala bidang pula agar tidak ketinggalan dengan kompetitor lain. Peningkatan yang dilakukan misal meningkatkan kompetensi SDM dengan melakukan pelatihan, workshop dan lain-lain. Meningkatkan kualitas Produk, palayanan dan fasilitas, meningkatatkan Brand Image (fasilitas, kompetensi, budaya kerja dan juga efektivitas PR) dan juga melakukan inovasi - inovasi bisnis agar tidak tertinggal dengan kompetitor lain yang juga mengikuti perkembangan jaman.

Hal yang serupa juga dilakukan oleh hotel Majapahit Surabaya, yang hingga kita diyakini tetap menjadi salah satu ikon lingkungan yang juga memberikan karakter kuat terhadap perjuangan masyarakat Surabaya. hotel Majapahit adalah sebuah hotel butik 
bintang lima di Surabaya dan salah satu hotel mewah di Indonesia. Dibangun pada tahun 1910, dengan nama Oranje Hotel (nama keluarga Kerajaan Belanda) oleh Lucas Martin Sarkies dari keluarga yang terkenal. The Strand di Rangoon, dan Eastern \& Oriental di Penang, Hotel Majapahit adalah hotel klasik dan kebanggaan nasional. Hotel ini memiliki sejarah yang benar-benar mengesankan,, dengan memadukan romansa dan keanggunan. Arsitektur yang anggun serta membangkitkan lansekap taman di sekitar bangunan, gaya colonial dan menawarkan berbagai fasilitas. Hotel ini bahkan menyediakan presidensial suites terbesar di Asia, dengan luas 800 meter persegi. (www.hotel-majapahit.com)

Sejarah The Majapahit Hotel Terletak di pusat kota Surabaya, kota terbesar kedua di Indonesia dan pelabuhan perdagangan sejak abad ke-15, majapahit telah mengukir nama atas sejarah yang cukup panjang. Dibangun pada tahun 1910, dengan nama Oranje Hotel nama keluarga Kerajaan Belanda) oleh Lucas Martin Sarkies dari keluarga yang terkenal. The Strand di Rangoon, dan Eastern \& Oriental di Penang, Hotel Majapahit adalah hotel klasik dan kebanggaan nasional. 1936: fasade hotel diperluas dan dibangun dengan gaya Art Deco Charlie Chaplin dan Paulette Goddard menghadiri pembukaan perluasan hotel. Perluasan tersebut berfungsi sebagai lobi dengan toko yang menjual kue dan es krim dengan nama "Hoen Kwee", dengan toko alat tulis Belanda "Van Drop". Pada tahun 1942 pada saat perang dunia kedua tiba di pulau Jawa, Hotel Oranje diambil alih oleh Jepang, dan berubah nama menjadi "Yamato Hoteru" atau "Hotel Yamato" selama tiga setngah tahun pendudukan Jepang. Tahun 1945 ketika revolusi terjadi di Surabaya, hotel Yamato berubah nama menjadi Hotel Merdeka. Beranjak pada tahun 1946 hotel kembali dikelola oleh keluarga Sarkies dan mengalami perubahan nama menjadi Hotel LMS (Lucas Martin Sarkies). Hingga pada tahun 1969 berubah nama menjadi hotel Majapahit. Nama kelima dalam kurun waktu 60 tahun, dipertahankan oleh pemilih baru. Pada tahun 1946, setelah 2 tahun, mengalami restorasi, hotel Majapahit buka kembali dengan nama Mandarin Oriental Hotel Majapahit, Surabaya, sebuah hotel bintang lima, pada tahun 2006 tepatnya tanggal 22 September, setelah 10 tahun Mandarin Oriental Hotel Grup beroperasi, Hotel Majapahit bangkit dengan managemen sendiri sebagai hotel bintang 5 berskala internasional.

Dari keterangan di atas dan juga berdasarkan hasil interview yang didapat dari dua sampel, maka dapat dijelaskan lebih lanjut mengenai keunggulan kompetitif apa saja yang didapatkan hotel yang dikategorikan sebagai bangunan warisan budaya ini, diantaranya adalah: pertama: Kedua hotel Inna Garuda dan hotel majapahit berada pada kelas tersendiri dan berbeda dari hotel lain pada umumnya, terutama dengan hotel yang berkonsep modern. Kedua: Kedua hotel memiliki nilai lebih khusunya bagi pemerintah dan tamu-tamu penting kenegaraan, hotel dijadikan bukan hanya sekedar fasilitas akomodasi namun juga sebagai tempat dimana para tamu bisa merasakan budaya sejarah dari tempat tersebut.

Ketiga: Hotel diutamakan sebagai tempat pilihan untuk menginap ketika diadakan acara acara besar tingkat nasional seperti peringatan hari pahlawan yang jatuh pada setiap tanggal 10 November dan hari Kemerdekaan Indonesia setiap tanggal 17, Hotel Majapahit merupakan hotel yang dipilih untuk menjadi pusat perayaan hari berserjarah tersebut serta dijadikan sebagai acara-acara besar tingkat internasional. Hotel Grand Inna Yogyakarta berlokasi di kawasan Ring 1, Daerah Istimewa Yogyakarta menggunakan istilah ring untuk kawasan Malioboro termasuk Ring 1, Kawasan Mangkabumi termasuk Ring 2, dan luar perbatasan Daerah Istimewa Yogyakarta termasuk Ring 3. Hal ini mendapatkan tanggapan baik daerah online travel agent. 


\section{Analisis Tantangan Hotel Sebagai Warisan Budaya Berwujud}

Berdasarkan data-data yang didapatkan, baik melalui kajian pustaka dan hasil interview yang didapat dari dua sampel, maka dapat dijelaskan lebih lanjut mengenai tantangan apa saja yang dihadapi pihak manajemen hotel dalam statusnya sebagai bangunan warisan budaya, adapun tantangan tersebut adalah: Peertama: Kurangnya kesadaran dan kepedulian masyarakat akan pentingnya warisan budaya yang bukan hanya dari segi kesenian, namun juga dari segi bangunan. Kedua: Merubah persepsi masyarakat bahwa heritage hotel bukanlah hotel tua yang jelek fasilitasnya. Secara usia bangunan memang sudah tua, namun fasilitas dan prasarana tetap mengikuti perkembangan jaman. Ketiga: Merubah persepsi masyarakat bahwa heritage hotel bukanlah hotel mahal, heritage hotel dapat dinikmati dan digunakan oleh siapa saja, karena harga yang ditawarkan cukup terjangkau. Keempat: Hotel harus selalu melakukan koordinasi dengan asosiasi atau lembaga heritage sebelum melakukan pemugaran atau revitalisasi. Kelima: Hotel tidak boleh merubah struktur bangunan utama secara fisik. Keenam: Hotel harus selalu melakukan pemeliharaan secara rutin. 7. Hotel harus mempertahankan bentuk asli bangunan, khusunya bagian yang menandakan bentuk ragam bangunan tertentu. 8 . Hotel tidak dapat melakukan pemugaran pada seluruh bagian bangunan, karena ada beberapa peraturan yang harus diikuti dan ada beberapa bagian yang tidak boleh dilakukan pemugaran ataupun revitalisasi, benar benar hanya sebatas pemeliharaan saja. 9. Hotel harus selalu mengutamakan keterpaduan antara berbagai kepentingan; pelaku bisnis, masyarakat, pemerintah daerah, pemerintah agar tidak ada pihak yang merasa dirugikan dengan keberadaan bangunan hotel atau dengan status hotel yang dikategorikan sebagai bangunan warisan budaya. 10. Semakin banyaknya hotel baru yang menawarkan konsep modern dan lebih kekinian

\section{Analisis Strategi Yang Telah, Sedang Dan Akan Dilakukan Manajemen Hotel Dalam Mempertahankan Statusnya Sebagai Warisan Budaya Berwujud}

Kedua hotel, baik hotel Inna Garuda maupun Hotel Majapahit adalah hotel yang menjadi ikon Indonesia dimata dunia atau turis manca negara dan tentu juga menjadi kebanggaan daerah masing-masing. Banyak hal yang telah dilakukan kedua hotel untuk tetap bisa bertahan dan bahkan bersaing dengan hotel-hetel modern lainnya di Indonesia. Sebagai hotel dengan basis manajemen moderen, maka keduanya secara maksimal memanfaatkan media sosial dan website yang merupakan media paling mudah mendapatkan informasi. Kedua hotel juga aktif memposting kabar terbaru yang terkait dengan hotel di media sosial dan website, termasuk gambar gambar bangunan untuk selalu memberikan informasi dan segala sesuatu yang baru terkait perkembangan hotel. Mereka juga berkerja sama dengan dengan perkumpulan heritage untuk saling berbagi informasi serta tidak lupa bekerjasama dengan Online Travel Agent untuk mempermudah calon pengunjung untuk mengetahui dan sampai ke hotel. 
Hal-hal lain yang selalu dilakukan oleh kedua hotel adalah mengadakan kegiatan yang melibatkan unsur heritage seperti hotel excursion yang dimiliki oleh Hotel Majapahit. Sebuah hotel tour yang disediakan oleh pihak manajemen untuk mengetahui sejarah Hotel Majapahit, Kamar bersejarah 33, dan fasilitas yang dimiliki hotel. Setelah mengikuti hotel tour akan mendapatkan coffee break di Lounge. Hotel Grand Inna Yogyakarta memperkenalkan makanan khas Yogyakarta dengan membuat Kampoeng Yogyakarta setiap Sabtu Malam.

Sebagai hotel yang menyandang bangunan warisan budaya bersejarah, pihak manajemen hotel selalu melakukan pemeliharaan, yaitu upaya menjaga dan merawat agar kondisi fisik Warisan Budaya tetap lestari dan terjaga kondisi aslinya. Kemudian untuk kondisi-kondisi tertentu, pihak hotel melakukan pemugaran, yaitu upaya pengembalian kondisi fisik Benda Warisan Budaya, Bangunan Warisan Budaya, dan Struktur Warisan Budaya yang rusak sesuai dengan keaslian bahan, bentuk, tata letak, dan teknik pengerjaan untuk memperpanjang usianya.

Sebagai hotel moderen, Inna Garuda dan hotel majapahit tetap melakukan pengembangan, yaitu peningkatan potensi nilai, informasi, dan promosi Warisan Budaya serta pemanfaatannya melalui penelitian, revitalisasi, dan adaptasi secara berkelanjutan serta tidak bertentangan dengan tujuan pelestarian. Hal tersebut dilakukan dengan strategi adaptasi, yaitu upaya pengembangan warisan budaya untuk kegiatan yang lebih sesuai dengan kebutuhan masa kini dengan melakukan perubahan terbatas yang tidak akan mengakibatkan kemerosotan nilai pentingnya atau kerusakan pada bagian yang mempunyai nilai penting. Selain itu, pihak manajemen hotel juga melakukan pengamanan yang cukup ketat dengan upaya menjaga dan mencegah warisan budaya ini dari ancaman dan gangguan.

Sebagai warisan budaya, pihak manajemen hotel juga melakukan pemanfaatan dan pendayagunaan Warisan Budaya untuk kepentingan sebesar-besarnya kesejahteraan masyarakat dengan tetap mempertahankan kelestariannya serta melakukan kerjasama dengan pihak ketiga yang lebih mengerti bagaimana bangunan warisan budaya seharusnya dipelihara dan dilestarikan, dan tidak semata-mata menjadi produk bisnis.

\section{KESIMPULAN}

Berdasarkan data yang telah dikumpulkan dan dianalisa, maka kesimpulan yang didapatkan dari penelitian ini adalah:

1. Terkait analisis klasifikasi berdasarkan kajian pustaka dan hasil interview hotel sebagai warisan budaya yang berwujud diklasifikasikan enak katergori pertama: Hotel memiliki nilai kelangkaan, yaitu karya arsitekturnya merupakan sesuatu yang langka. Kedua: Sebuah Hotel yang memiliki nilai sejarah yaitu hotel yang lokasinya menjadi tempat terjadinya sejarah penting. Ketiga: Hotel memiliki nilai superlativitas, yaitu memiliki predikat ter-, misalnya tertua, terbesar, tertinggi, terpanjang. Keempat: Hotel memiliki nilai kezamanan, yaitu karya yang mewakili suatu jenis ragam bangunan tertentu. Kelima: Hotel memiliki nilai estetika, yaitu mempunyai keindahan bentuk struktur dan ornamen tertentu. Keenam: Hotel memberikan pengaruh, yaitu keberadaanya akan meningkatkan citra lingkungan sekitarnya. 
2. Analisis terkait motif manajemen dalam mempertahankan keaslian hotel dilatarbelakangi pada sembilan komponen, yakni: Pertama: Hhotel dianggap mempunyai nilai penting bagi sejarah, ilmu pengetahuan dan budaya serta benda alam yang dianggap memiliki nilai penting bagi sejarah, ilmu pengetahuan dan kebudayaan. Kedua: Hotel turut serta memelihara kelangsungan hidup bangunan yang memiliki nilai sejarah dengan cara memanfaatkannya sesuai dengan fungsi masa sekarang tanpa menghilangkan ciri aslinya. Ketiga: Hotel turut andil dalam menyebarluaskan informasi tentang pentingnya bangunan warisan budaya dan sejarah yang mengikutinya. Keempat: Hotel turut serta dalam mempertahankan citra negara Indonesia sebagai negara yang memiliki peninggalan arsitektur yang kaya. Kelima: Hotel memiliki nilai lebih dari hanya sekedar menyediakan akomodasi. Keenam: Hotel yang memiliki keunikan tersendiri. Ketujuh: Hotel sebagai warisan budaya, maka hotel berharap dapat menarik dan juga tentunya mendapatkan market yang lebih luas, misalkan niche market yang menyukai hal-hal yang berbau heritage. Kedelapan: Hotel sebagai warisan budaya, maka hotel berharap dapat berada pada kelasnya tersendiri, terlepas dari kategori bintang yang dipegangnya, namun hotel mempunyai kategori yang jarang dimiliki hotel lain pada umumnya yaitu heritage hotel. Kesembilan: Hotel memiliki nilai seni yang lebih tinggi dibandingkan hotel yang mengambil konsep heritage.

3. Analisis keunggulan kompetitif status hotel sebagai warisan budaya berwujud, maka dapat disimpulkan bahwa: pertama: Kedua hotel Inna Garuda dan hotel majapahit berada pada kelas tersendiri dan berbeda dari hotel lain pada umumnya, terutama dengan hotel yang berkonsep modern. Kedua: Kedua hotel memiliki nilai lebih khusunya bagi pemerintah dan tamu-tamu penting kenegaraan, Ketiga: Hotel diutamakan sebagai tempat pilihan untuk menginap ketika diadakan acara acara besar tingkat nasional seperti peringatan hari pahlawan yang jatuh pada setiap tanggal 10 November dan hari Kemerdekaan Indonesia setiap tanggal 17.

4. Analisis tantangan hotel dalam mempertahan nilai hotel sebagai warisan budaya berwujud Peertama: membangkitkan kesadaran masyarakat akan pentingnya warisan budaya yang bukan hanya dari segi kesenian, namun juga dari segi bangunan. Kedua: Merubah persepsi masyarakat bahwa heritage hotel bukanlah hotel tua yang jelek fasilitasnya. Ketiga: Merubah persepsi masyarakat bahwa heritage hotel bukanlah hotel mahal, Keempat: Hotel harus selalu melakukan koordinasi dengan asosiasi atau lembaga heritage sebelum melakukan pemugaran atau revitalisasi. Kelima: Hotel tidak boleh merubah struktur bangunan utama secara fisik. Keenam: Hotel harus selalu melakukan pemeliharaan secara rutin. Ketujuh: Hotel harus mempertahankan bentuk asli bangunan. Kedelapan: Hotel tidak dapat melakukan pemugaran pada seluruh bagian bangunan: Kesembilan: Hotel harus selalu mengutamakan keterpaduan antara berbagai kepentingan; pelaku bisnis, masyarakat, pemerintah daerah dan lainlain.

5. Analisis strategi yang telah, sedang dan akan dilakukan manajemen hotel dalam mempertahankan statusnya sebagai warisan budaya berwujud dengan maksimal memanfaatkan media sosial dan website yang merupakan media paling mudah mendapatkan informasi. Kedua hotel juga aktif memposting kabar terbaru yang terkait dengan hotel di media sosial dan website, termasuk gambar gambar bangunan untuk 
selalu memberikan informasi dan segala sesuatu yang baru terkait perkembangan hotel. Mereka juga berkerja sama dengan dengan perkumpulan heritage untuk saling berbagi informasi serta tidak lupa bekerjasama dengan Online Travel Agent untuk mempermudah calon pengunjung untuk mengetahui dan sampai ke hotel.

\section{SARAN}

Dari kesimpulan penelitian diatas, maka dapat dikemukakan saran-saran bagi manajamen Hotel Majapahit dan Hotel Grand Inna dari sumber penelitian ini adalah: 1 . Tetap mempertahan keaslian bentuk dari bangunan hotel bersejarah, dengan jalan tidak sembarangan merubah dan mengganti keaslian tata letak serta bentuk dari bangunan hotel bersejarah. 2. Untuk beberapa peralatan maupun furniture yang sudah berumur tua, disarankan untuk lebih ditangani secara khusus dengan menggunakan bahan dan peralatan yang tepat. 3. Disediakan budget khusus untuk pemeliharaan gedung beserta fasilitasnya, agar kelestariannya lebih terjaga. 4. Program promosi dan pemasaran hotel harus sering dilakukan, mengingat banyaknya hotel-hotel sejenis yang lebih modern dan menawarkan paket menarik. 5. Membuat program promosi Food \&Beverage dan Spa dengan paket yang menarik. 6. Bagi para tamu yang menginap, diberikan informasi mengenai konsep hotel heritage, sejarah hotel itu sendiri, dan pihak pemasaran membuat semacam program wisata sejarah di dalam hotel itu sendiri.

\section{DAFTAR PUSTAKA}

Chon, K. S., Bauer, T., \& Mckercher, B. (2012). Sex and tourism: journeys of romance, love, and lust. Routledge.

Davidson, G. Mc Conville. 1991. A Heritage Handbook. St. Leonard, NSW.

Hall, C. M., \& McArthur, S. (Eds.). (1993). Heritage management in New Zealand and Australia: visitor management, interpretation and marketing. Oxford University Press, USA.

Hendro, E. P. (2015). Pelestarian kawasan konservasi di Kota Semarang. Jurnal Konservasi Cagar Budaya Borobudur, 9(1), 17-28.

Kleden, U. C., \& Fanani, F. (2015). Harmonisasi Ketentuan Peruntukan Bangunan Cagar Budaya Dalam Perspektif Regulasi Di Kawasan Budaya Kotabaru, Kota Yogyakarta-DIY. ReTII.

Margono, S. (2007). Metodologi penelitian pendidikan: komponen MKDK. Jakarta: Rineka Cipta.

Pawito, P. (2007). Penelitian komunikasi kualitatif. Lkis Pelangi Aksara. 
Satriani, Putra, M. A., Nurwahidah, \& Surur, F. (2016). Kebijakan Pelestarian Bangunan Cagar Budaya Sebagai Identitas Kota.

Siregar, S. (2013). Metode Penelitian Kuantitatif: Dilengkapi Perbandingan Perhitungan Manual dan SPSS, Edisi 1. Jakarta. Indonesia: Kencana Prenadamedia Group.

Sutopo, A. H., \& Arief, A. (2010). Terampil Mengolah Data Kualitatif Dengan NVIVO. Jakarta: Prenada Media Group.

Tonapa, Y. N., Rondonuwu, D. M., \& Tungka, A. E. (2015). Kajian Konservasi Bangunan Kuno Dan Kawasan Bersejarah Di Pusat Kota Lama Manado. SPASIAL, 2(3), 121130.

UNSECO. Intangible Cultural Heritage.

Wehmeier, S. (2005). Oxford Advanced Learner's Dictionary, Oxford: Oxford University Press.

Xie, P. F. (2015). Industrial heritage tourism. Channel View Publications.

Zebua, M. (2016). Inspirasi Pengembangan Pariwisata Daerah. Yogjakarta, Indonesia: Deepublish.

Zulkarnain, I. (2012). Studi Penyusunan Kriteria Perencanaan Pelestarian Kawasan Bersejarah Sunda Kelapa Menggunakan Metode Analytical Hierarchy Process (AHP) . 